\title{
Research Article: Attitude of farmers towards drip irrigation system
}

\section{Narpat Singh and K.L. Dangi}

Article Chronicle: Received :

16.03.2017;

Revised :

05.12.2017;

Accepted :

21.12.2017

SUMMARY : This study was conducted in Chittorgarh and Udaipur district of Rajasthan. The majority of respondents has expressed favourable attitude towards drip irrigation system. It was noticed that farmers had higher of agreement with statement i.e. the best method for water scarcity conditions and least level of agreement with statement i.e. DIS does not require construction of irrigation channels and check basin.

How to cite this article : Singh, Narpat and Dangi, K.L. (2018). Attitude of farmers towards drip irrigation system. Agric. Update, 13(1): 14-17; DOI : 10.15740/HAS/AU/13.1/14-17.

KeY WoRDS:

Attitude, Farmers,

Drip irrigation system

Author for correspondence :

Narpat Singh

Department of

Extension Education,

OPJS University, Churu

(Rajasthan) India

See end of the article for

authors' affiliations 